\title{
Development of an Ultraviolet A1 Light Emitting Diode-based Device for Phototherapy
}

\author{
Shunko A. Inada ${ }^{*}{ }^{, 1,3}$, Satoshi Kamiyama ${ }^{1}$, Isamu Akasaki ${ }^{1}$, Kan Torii ${ }^{3}$, Takuya Furuhashi ${ }^{3}$, Hiroshi \\ $\mathrm{Amano}^{2}$ and Akimichi Morita ${ }^{3}$ \\ ${ }^{1}$ Department of Materials Science and Engineering, Faculty of Science and Technology, Meijo University, 1-501 \\ Shiogamaguchi Tempaku-ku, Nagoya 468-8502, Japan \\ ${ }^{2}$ Graduate School of Engineering, Akasaki Research Center, Nagoya University, Furo-cho, Chikusa-ku, Nagoya 464- \\ 8603, Japan \\ ${ }^{3}$ Department of Geriatric and Environmental Dermatology, Nagoya City University Graduate School of Medical \\ Sciences, Nagoya 467-8601, Japan
}

\begin{abstract}
We developed a novel phototherapy device based on an ultraviolet light emitting diode (UV LED) with a peak wavelength of $365 \mathrm{~nm}$ and the full width at half maximum of $10 \mathrm{~nm}$. The equipment comprised a $16 \times 16(50 \mathrm{~cm} \times 50 \mathrm{~cm})$ UV LED matrix. The system was designed to irradiate only the diseased part of the skin. To evaluate the characteristics of this device, we compared consumed power, irradiation intensity, uniformity of the irradiation intensity, rise time and stability of the irradiation intensity, and in vivo irradiation of mice between a conventional UVA1 (340-400 nm) phototherapy device and the UV LED device. The UVA1 LED device exhibited more desirable characteristics than the UVA1 lamp device, i.e., fewer thermal effects on in vitro and in vivo systems. Furthermore, to evaluate the efficacy of both light sources, cultured $\mathrm{T}$ cells were irradiated and the induction of apoptosis was analyzed. Both light sources efficiently induced apoptosis.
\end{abstract}

Keywords: Apoptosis, phototherapy, ultraviolet light emitting diode (UV LED).

\section{INTRODUCTION}

Ultraviolet (UV) irradiation for phototherapy is commonly used to treat refractory skin disease. A fluorescent light bulb that emits a narrow-band wavelength between 311 and $313 \mathrm{~nm}$ (narrow-band UVB) is used to treat refractory skin diseases such as psoriasis vulgaris and vitiligo vulgaris $[1,2]$. A wavelength range of $340-400 \mathrm{~nm}$ (UVA1) is used to treat atopic dermatitis and urticaria pigmentosa [3, 4]. The use of a fluorescent light bulb as the light source, however, has several disadvantages: (1) Phototherapy systems using a fluorescent light bulb require many square meters of floor space and consume approximately 3.5-5 KW of electricity; (2) The light source has a relatively short lifetime and contains toxic substances; (3) Irradiation of healthy tissue is difficult to avoid when using a large-area irradiation device, leading to unwanted exposure; (4) The heat radiating from the light source is uncomfortable for the patients; and (5) Medical workers are also exposed to UV irradiation while operating the system.

To address these problems, a device based on a newlydeveloped light emitting diode (LED) should be considered for UVA1 irradiation. The single-chip GaN-based UV LED is relatively small $(350 \mu \mathrm{m} \times 350 \mu \mathrm{m})$ [5]. This UV LED can

*Address correspondence to this author at the Department of Materials Science and Engineering, Faculty of Science and Technology, Meijo University, 1501 Shiogamaguchi Tempaku-ku, Nagoya 468-8502, Japan;

Tel: +81-052-832-1151; Fax: +81-052-832-1244;

E-mail:m0641503@ccalumni.meijo-u.ac.jp be operated with a dry battery and can be used to irradiate only the diseased skin. Moreover, the lifetime of the LED is three times longer than that of normal fluorescent light bulbs, and the LED contains no toxic substances [6]. In addition, the UV LED has a narrower spectrum range than the fluorescent light bulb. The development of a UV LED device based on a III-nitride semiconductor was reported [7-9]. The emission efficiency of the UV LED, however, is significantly decreased at emission wavelengths shorter than $360 \mathrm{~nm}$ [10]. Although a visible LED and laser diode have been used to treat acne and facial rejuvenation [11-13], to our knowledge there are no reports of UV LED-based phototherapy.

We previously compared the effects of UVA1 LED (wavelength $365 \mathrm{~nm}$, full width at half maximum (FWHM) of $10 \mathrm{~nm}$, output power $1400 \mathrm{~W} / \mathrm{cm}^{2}$; ANUJ5010, Panasonic Co., Ltd.) with conventional UVA1 fluorescent lamp (340$400 \mathrm{~nm}$ ) phototherapy equipment (Partial Body UVA1 Irradiation Sellamed 2000 System; Sellas, Germany) [14]. Jurkat $\mathrm{T}$ cells, a leukemic $\mathrm{T}$ cell line, were used to evaluate the efficacy of phototherapy. Apoptosis and necrosis were induced in Jurkat $T$ cells irradiated by the UVA1 LED and conventional UVA1 lamp devices. The two different light sources had similar biologic effects. Both UVA1 light sources induced similar levels of apoptosis and necrosis [14].

In the present study, we developed a phototherapy system using the UVA1 LED. The UVA1 LED phototherapy device comprised a $16 \times 16(50 \mathrm{~cm} \times 50 \mathrm{~cm})$ UV LED matrix. It can selectively irradiate the diseased skin without affecting 
neighboring healthy skin. The device takes a picture of the area of skin to be treated, and a computer program built into the device selects the areas to be irradiated.

We compared the consumed power, irradiation intensity, uniformity of the irradiation intensity, rise time and stability of the irradiation intensity, and temperature during in vivo exposure of irradiated mice between the UVA1 LED phototherapy device and conventional UVA1 lamp phototherapy device. We also compared the ability of the two devices to induce apoptosis.

\section{MATERIALS AND METHODS}

\section{Development of the UV LED Phototherapy Device}

We developed a phototherapy system containing UVA1 LEDs (wavelength $365 \mathrm{~nm}$, FWHM 7 nm, output power 250 $\mathrm{mW}$ ) obtained from Nichia Corporation (Fig. 1). The device comprised a $16 \times 16(50 \mathrm{~cm} \times 50 \mathrm{~cm})$ UV LED matrix. The system takes a picture of the intended treatment area, and a computer program then selects the region to be irradiated. The energy efficiency of the UV LED is approximately $22 \%$; therefore, an aluminum heat sink with cooling water was used to cool the system. To prevent accidents, the system was controlled by sensors that monitor electricity, water leakage, seismic intensity, and heat.

\section{Evaluation of Irradiation Intensity}

For all of the comparisons of the two devices, the number of LEDs used in the UV LED device was decreased to match the size of the UVA1 lamp $(28 \mathrm{~cm} \times 24 \mathrm{~cm})$. To compare the irradiation intensity of the UV LED and UVA1 devices, the light source was fixed above the center of an irradiation detector (IL1700 Research Radiometer SED005, International Light Technologies, Peabody, MA). The height of the light source was varied from $1 \mathrm{~cm}$ to $50 \mathrm{~cm}$ and the mean irradiation intensity was measured at $5-\mathrm{cm}$ intervals.

\section{Evaluation Uniformity of the Irradiation Intensity}

To compare the uniformity of irradiation intensity of the UVA1 LED phototherapy and UVA1 lamp phototherapy devices, the light source was fixed above the center of the irradiation detector and irradiation intensity was measured at $5-\mathrm{cm}$ intervals across the diameter while the height of the light source was varied from $1 \mathrm{~cm}$ to $50 \mathrm{~cm}$ at $5-\mathrm{cm}$ intervals.

To compare the uniformity of the irradiation intensity of the UV LED and UVA1 lamp devices at 10, 20, 30, 40, and $50 \mathrm{~mW} / \mathrm{cm}^{2}$, the light source was fixed above the center of the irradiation detector. Irradiation intensity was measured at 5 -cm intervals across the diameter.

\section{Evaluation of the Rise Time and Stability of the Irradiation Intensity}

To compare the rise time of the irradiation intensity of the UV LED and UVA1 lamp devices, the light source was fixed above the center of the power meter (VEGA PD300UV OPHIR, North Logan, UT). Rise time was measured until the irradiation intensity reached a steady state from the power input. The stability of the irradiation intensity was measured for $1 \mathrm{~h}$.

\section{Evaluation of Temperature Characteristics}

To compare the temperature characteristics, mice (C57BL/6) were irradiated for $20 \mathrm{~min}$ at 3 irradiation intensities $\left(10,20\right.$, and $30 \mathrm{~mW} / \mathrm{cm}^{2}$, which corresponded to doses of 12,24 , and $36 \mathrm{~J} / \mathrm{cm}^{2}$, respectively), and the temperature of both the skin surface and body of the mice was measured every $2 \mathrm{~min}$. The skin surface temperature was measured by thermography (CPA-0306 CHINO Co., Ltd., Tokyo, Japan) and the body temperature was measured using a thermoelectric couple (CT-470 Custom Laboratory Thermocouples, St. Francis, MN) placed in the rectum. The experiment was performed 3 times at each irradiation intensity.

\section{Evaluation of Temperature Characteristics Using Selective Irradiation Function}

To confirm the selective irradiation function of the UV LED device, mice with a body size of approximately $8 \mathrm{~cm} \mathrm{x}$ $3 \mathrm{~cm}$ were irradiated at an intensity of $30 \mathrm{~mW} / \mathrm{cm}^{2}$ for 20 min. The experiment was discontinued if the state of the mice became unresponsive while being irradiated by the UVA1 lamp phototherapy device. The temperature of both the skin surface and body of the mice was measured every 2 min. To compare with the UVA1 lamp, the same experiment was performed using a board with an $8 \mathrm{~cm} \times 3 \mathrm{~cm}$ hole placed between the light source and the mouse. The skin surface temperature and body temperature were measured as described above.

\section{Evaluation of Temperature Characteristics Using Far- Infrared Resonance Filter}

To determine if the increased temperature in the skin surface and body was due to the UV light or the far-infrared rays produced by the light source, the mice were irradiated using a far-infrared resonance filter (size: $5 \mathrm{~cm} \times 5 \mathrm{~cm}$, transparent wavelength: 250-2000 nm, HAF-50S-15H, SIGMA KOKI Co., Ltd., Tokyo, Japan). To compare the effect of the filter, a board with a $5 \mathrm{~cm} \times 5 \mathrm{~cm}$ hole was placed between the light source and the mice. The mice were irradiated for $20 \mathrm{~min}$ at an intensity of $30 \mathrm{~mW} / \mathrm{cm}^{2}$ using the UVA1 LED phototherapy and UVA1 lamp phototherapy devices. The temperature of both the skin surface and body of the mice was measured every $2 \mathrm{~min}$ as described above.

\section{Evaluation of Temperature Characteristics of Three Types Mediums}

Three types of media: Dulbecco's Phosphate Buffered Saline (PBS), RPMI1640 (with phenol red), and RPMI1640 (without phenol red) (Sigma Aldrich Co., Ltd., St. Louis, MO) and dishes of three different diameters, $3.5 \mathrm{~cm}, 6 \mathrm{~cm}$, and $10 \mathrm{~cm}$, were used for temperature analysis. The temperature of the medium was measured every 2 min using a thermoelectric couple (CT-470 Custom). The number of the UVA1 LEDs was decreased to match the size of the UVA1 lamp. The amount of medium put into each dish was as follows: $3.5-\mathrm{cm}$ dish $=2 \mathrm{~mL}, 6-\mathrm{cm}$ dish $=5 \mathrm{~mL}$, and $10-$ $\mathrm{cm}$ dish $=10 \mathrm{~mL}$. The experiment was performed 3 times for each condition.

\section{Evaluation of Cellular Apoptosis}

To confirm the positive control of cellular apoptosis, Jurkat T cells were cultured with RPMI1640 (with phenol 
UVA1-LED
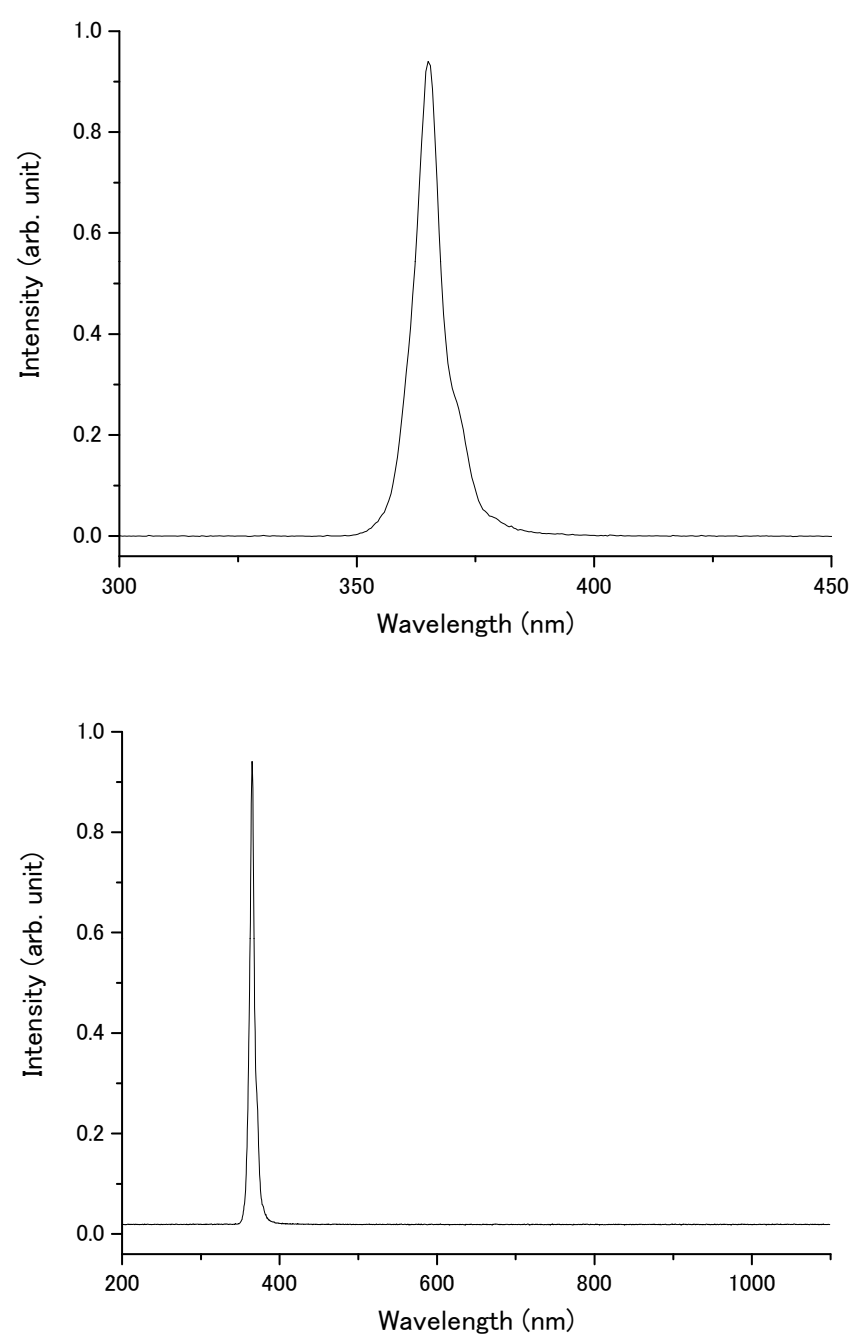

UVA1-Lamp
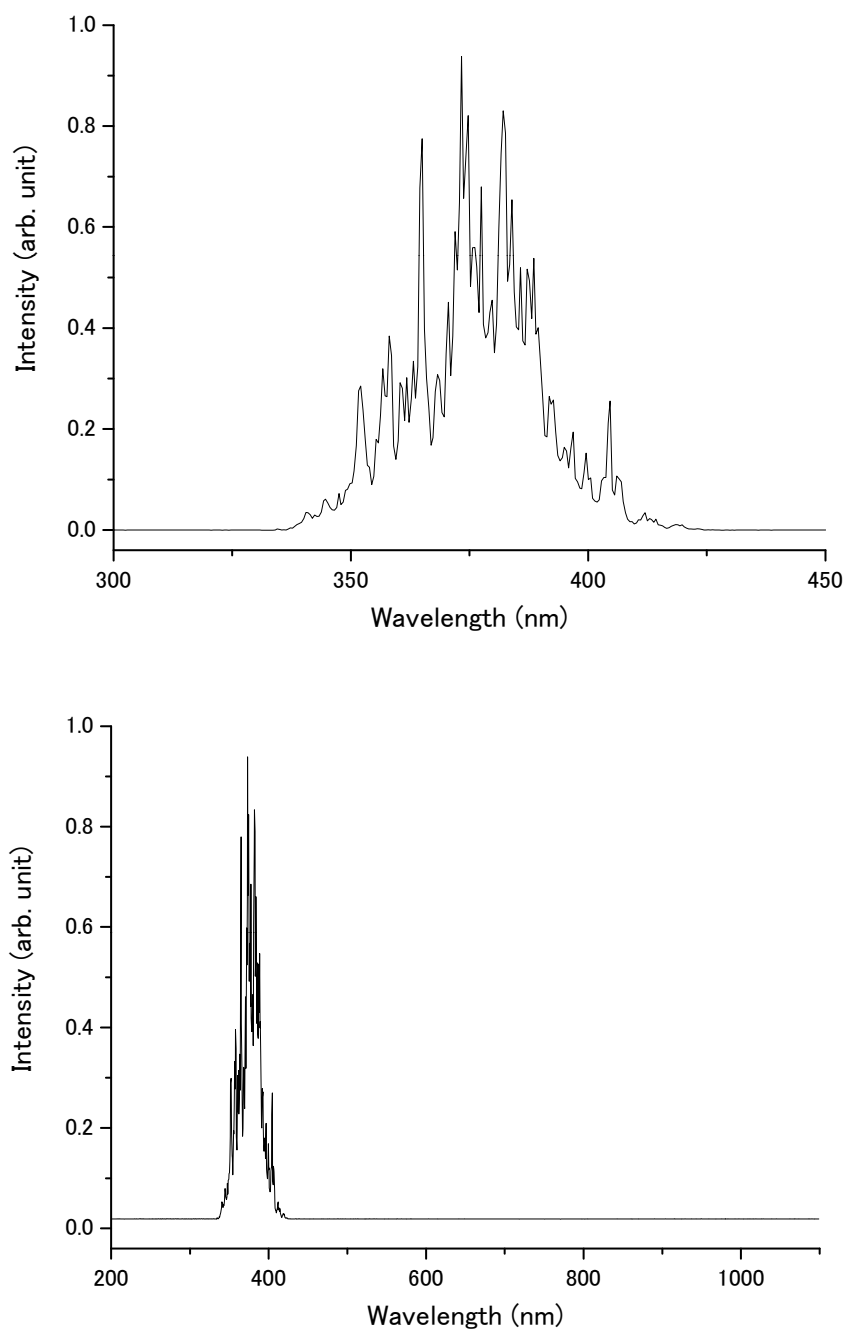

Fig. (1). UV LED and UVA1 lamp spectrums. The UV LED device has a peak wavelength of $365 \mathrm{~nm}$ and full width at half maximum (FWHM) of $7 \mathrm{~nm}$. The UVA1 lamp has a peak wavelength of $373 \mathrm{~nm}$ and FWHM of $40 \mathrm{~nm}$. The light source comprises UV, blue, and infrared filters. The top panels show only the UVA1 wavelength spectrum. The bottom panels show a larger spectrum (200 to $1000 \mathrm{~nm})$.

red) $/ 10 \%$ fetal bovine serum (Equitech Bio, Inc., Kerrville, TX)/50 mM HEPES buffer (Sigma-Aldrich) $/ 5 \mathrm{mM}$ sodium pyruvate (Sigma-Aldrich) $/ 0.5 \mathrm{mM}$ Minimal Essential Medium non-essential amino acids solution (GIBCO) $/ 5 \mathrm{x}$ antibiotic-antimycotic (GIBCO) in $5 \% \mathrm{CO}_{2}$ at $37^{\circ} \mathrm{C}$. Jurkat $\mathrm{T}$ cells were diluted to $0.5 \times 10^{6}$ cells $/ \mathrm{mL}$ with PBS.

A broadband UVB (BB-UVB) light source (FL20S E30/DMR, Toshiba Co., Ltd., Tokyo, Japan) was fixed at a height of $20 \mathrm{~cm}$ above the cultures and the irradiation intensity was $0.61 \mathrm{~mW} / \mathrm{cm}^{2}$. Twenty-four hours after either control, sham irradiation, or BB-UVB irradiation at doses of 20,40 , and $80 \mathrm{~mJ} / \mathrm{cm}^{2}$, the cells were collected to examine cellular apoptosis using a flow cytometer (BD FACS Canto II, Becton Dickinson Co., Ltd., Princeton, NJ). The cells were stained with propidium iodide and annexin Vfluorescein isothiocyanate (Medical \& Biological Laboratories Co., Ltd., Nagoya, Japan).
Irradiation intensities of control, sham irradiation, and 10 $\mathrm{J} / \mathrm{cm}^{2}, 20 \mathrm{~J} / \mathrm{cm}^{2}$, and $30 \mathrm{~J} / \mathrm{cm}^{2}$ UVA1 irradiation were applied to three dishes using the UVA1 phototherapy devices. The number of UVA1 LEDs was decreased to match the size of the UVA1 lamp. The UV LED was fixed at a height of 35 $\mathrm{cm}$. The UVA1 lamp device was fixed at a height of $63 \mathrm{~cm}$, and the irradiation intensity was $10 \mathrm{~mW} / \mathrm{cm}^{2}$.

\section{Statistical Methods}

We compared the UV LED and UVA1 devices using a two-tailed t-test. Results are expressed as the means \pm SD. A P value of less than 0.05 was considered significant.

\section{RESULTS}

\section{Evaluation of Consumed Power}

The power consumed by the UVA1 LED phototherapy and UVA1 lamp phototherapy devices was measured using 
the same intensity and lamp size. The UVA1 LED consumed one-third the power of the UVA1 lamp (Fig. 2).

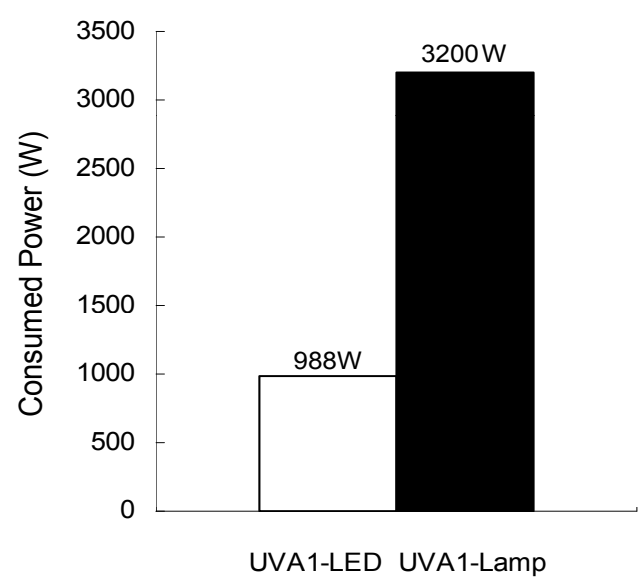

Fig. (2). Power consumption of the UV LED and UVA1 lamps was compared at the same intensity and dimension. The UV LED can irradiate at the same intensity and size using one-third the power required by the UVA1 lamp.

\section{Evaluation of Irradiation Intensity}

The irradiation intensity of both the UVA1 LED and UVA1 lamp devices was measured from a height ranging from $1 \mathrm{~cm}$ to $50 \mathrm{~cm}$ at $5-\mathrm{cm}$ intervals. The UVA1 LED had lower intensity than the UVA1 lamp (Fig. 3a). At a distance between $6 \mathrm{~cm}$ and $10 \mathrm{~cm}$, the UVA1 LED produced uniform intensity.

\section{Evaluation of Uniformity of Distance-Dependent Irradiation Intensity}

Irradiation intensity was measured across the diameter at $5-\mathrm{cm}$ intervals with the height of light source ranging from 1 $\mathrm{cm}$ to $50 \mathrm{~cm}$ at $5-\mathrm{cm}$ intervals. The irradiation intensity of the UVA1 lamp decreased as the irradiation distance increased with a cosine function, and was uniform when the irradiation distance was smaller (Fig. 3b). The UVA1 LED, however, produced uniform irradiation independent of the irradiation distance.

\section{Evaluation of Irradiation Intensity Uniformity}

The light sources were fixed above the center of the detector at distances that produced 10,20,30, 40, and 50 $\mathrm{mW} / \mathrm{cm}^{2}$ of irradiation. Irradiation intensity was measured across the diameter at $5-\mathrm{cm}$ intervals. The intensity at 10 and $20 \mathrm{~mW} / \mathrm{cm}^{2}$ was uniform (Fig. 3c). At 30, 40, and 50 $\mathrm{mW} / \mathrm{cm}^{2}$, however, the uniformity of the UVA1 lamp irradiation intensity decreased with a cosine function. In contrast, the UVA1 LED had a uniform intensity at each irradiation intensity.

\section{Evaluation of the Rise Time and Stability of the Irradiation Intensity}

Rise time was measured until the irradiation intensity reached a steady state. The intensity of the UVA1 lamp reached a steady state in approximately $1 \mathrm{~min}$, and the intensity of the UVA1 LED reached a steady state within a few seconds (Fig. 4a). The stability of irradiation intensity was measured for $1 \mathrm{~h}$. While the UVA1 lamp irradiation intensity fluctuated over the course of $1 \mathrm{~h}$ of observation, that of the UVA1 LED was stable (Fig. 4b).

\section{Evaluation of Skin and Body Temperature}

The temperature characteristics of mice were measured every 2 min for 20 min irradiation with the UVA1 LED and UVA1 lamp devices at intensities of 10,20 , and $30 \mathrm{~mW} / \mathrm{cm}^{2}$ (corresponding to irradiation intensities of 12,24 , and 36 $\mathrm{J} / \mathrm{cm}^{2}$ ) and compared. By the end of the observation period, body temperature was not significantly different between mice irradiated with the two devices (Fig. 5). With increasing irradiation intensity, however, the skin surface temperature of mice irradiated with the UVA1 lamp increased $8^{\circ} \mathrm{C}$ to $10^{\circ} \mathrm{C}$. In contrast, the skin surface temperature of mice irradiated with the UVA1 LED increased only $3^{\circ} \mathrm{C}$ to $4^{\circ} \mathrm{C}$. In the experiment using an irradiation intensity of $30 \mathrm{~mW} / \mathrm{cm}^{2}$ with the UVA1 lamp, the state of the mouse became unresponsive after $18 \mathrm{~min}$ and the experiment was discontinued. At that time, the body temperature was $40.5^{\circ} \mathrm{C}$, and the skin surface temperature was $60^{\circ} \mathrm{C}$.

\section{Evaluation of Temperature Characteristics Using the Selective Irradiation Function}

To confirm the selective irradiation function of the UVA1 LED phototherapy device, mice were irradiated at 30 $\mathrm{mW} / \mathrm{cm}^{2}$ for $20 \mathrm{~min}$, which was an intensity that could not be tested using the UVA1 lamp phototherapy device (see above). The temperature of both the skin surface and body as measured every $2 \mathrm{~min}$. To compare with the UVA1 lamp, the same experiment was performed using a board with an $8 \mathrm{~cm}$ x $3 \mathrm{~cm}$ hole placed between the light source and the mouse. The body and skin surface temperatures of mice irradiated using the UVA1 LED barely changed (Fig. 6). The body and skin surface temperatures of the mice irradiated with the UVA1 lamp, however, increased rapidly. Compared to the UVA1 LED, the UVA1 lamp increased the body temperature $5.1^{\circ} \mathrm{C}$ and the skin surface temperature $13.8^{\circ} \mathrm{C}$. These results suggest that the UVA1 LED can treat affected skin more intensively without heating the skin than the conventional UVA1 lamp.

\section{Evaluation of Temperature Characteristics Using a Far- Infrared Resonance Filter}

The mice were irradiated with the UVA1 LED and UVA1 lamp devices using a far-infrared resonance filter and the temperature of both the skin surface and body of the mice was measured to determine if the increase in the skin surface and body temperature was due to UV or far-infrared irradiation. The far-infrared resonance filter did not affect the body or skin surface temperatures in mice irradiated with the UVA1 LED device (Fig. 7). With the UVA1 lamp, however, the filter prevented an increase in the body $\left(3.4^{\circ} \mathrm{C}\right.$ without filter) and skin surface $\left(13.7^{\circ} \mathrm{C}\right.$ without filter) temperature. Thus, the increase in the body and skin surface temperature in mice irradiated with the UVA1 lamp was due to the emission of far-infrared rays. 


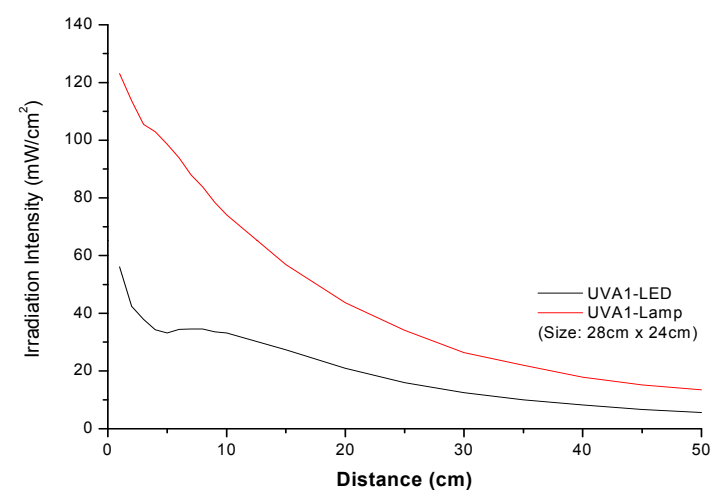

UVA1-LED
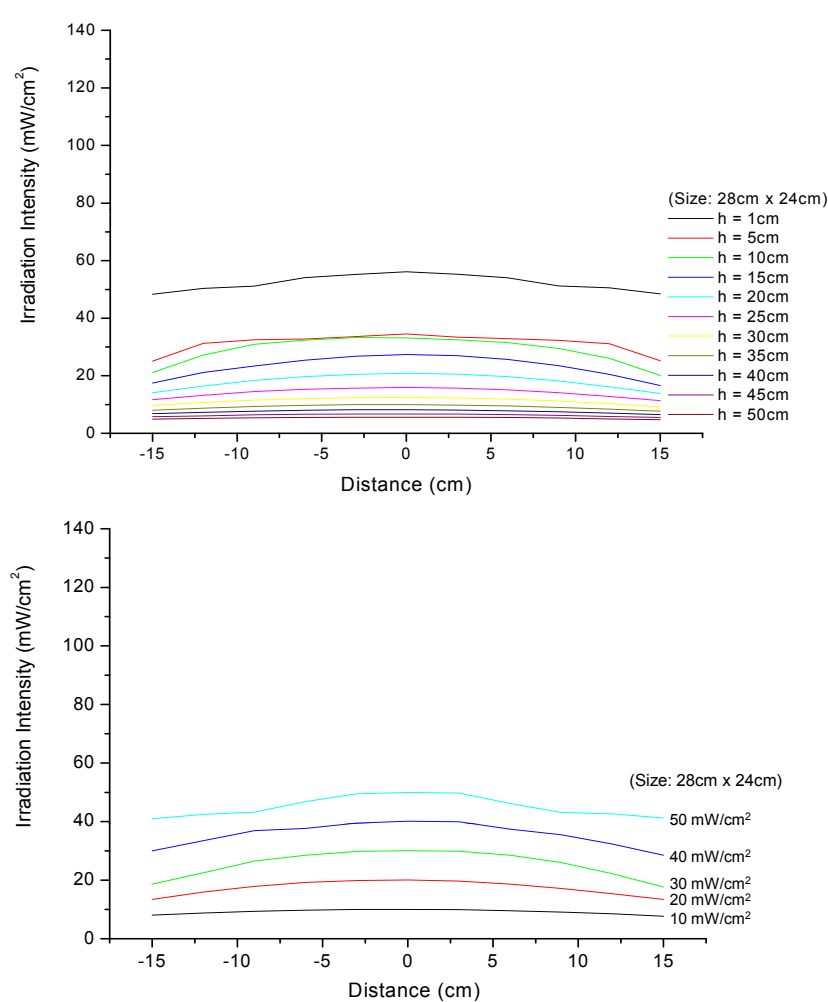

UVA1-Lamp
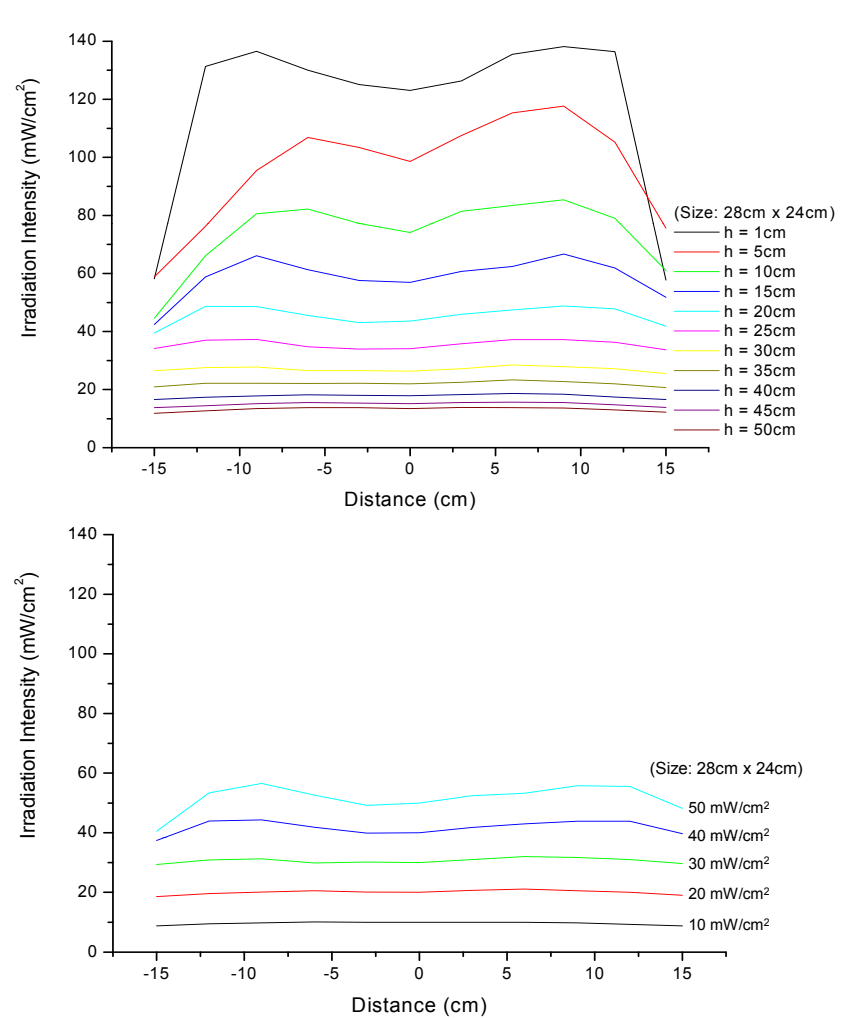

Fig. (3). The irradiation intensity and uniformity of irradiation intensity at 10, 20, 30, 40, and $50 \mathrm{~mW} / \mathrm{cm}^{2}$ of the UV LED and UVA1 lamp devices. (a) The UVA1 lamp had higher irradiation intensity than the UV LED device. From $6 \mathrm{~cm}$ to $10 \mathrm{~cm}$, however, the UV LED device exhibited uniform intensity. (b) At short irradiation distances, the UVA1 lamp irradiation intensity tended to vary with a cosine function. UV LED produced uniform irradiation intensity independent of the irradiation distance. (c) The UVA1 lamp intensity at 10 and $20 \mathrm{~mW} / \mathrm{cm}^{2}$ was uniform, but the irradiation intensity at 30,40 , and $50 \mathrm{~mW} / \mathrm{cm}^{2}$ varied with a cosine function. The UV LED at each irradiation intensity was uniform.

\section{Evaluation of Temperature Characteristics of Three Different-Sized Dishes}

We analyzed the thermal effects of UV irradiation on culture plates with diameters of $3.5,6$, and $10 \mathrm{~cm}$. The plates were irradiated at intensities of 10,20 , and $30 \mathrm{~mW} / \mathrm{cm}^{2}$ for 30 min with either the UVA1 LED or UVA1 lamp devices. The UVA1 lamp increased the temperature of the dishes, especially the $3.5-\mathrm{cm}$ dish, more than the UVA1 LED device
(Fig. 8). The larger the dish, the smaller the thermal effects of the UVA1 devices.

\section{Evaluation of Cellular Apoptosis}

Jurkat $\mathrm{T}$ cells were irradiated with a BB-UVB light source as a positive control. After irradiation with BB-UVB $\left(20,40\right.$, or $\left.80 \mathrm{~mJ} / \mathrm{cm}^{2}\right)$, the Jurkat $\mathrm{T}$ cells underwent apoptosis (Fig. 9). At a dose of $20 \mathrm{~mJ} / \mathrm{cm}^{2}$, the amount of apoptosis differed significantly between the $3.5 \mathrm{~cm}$ and 10 

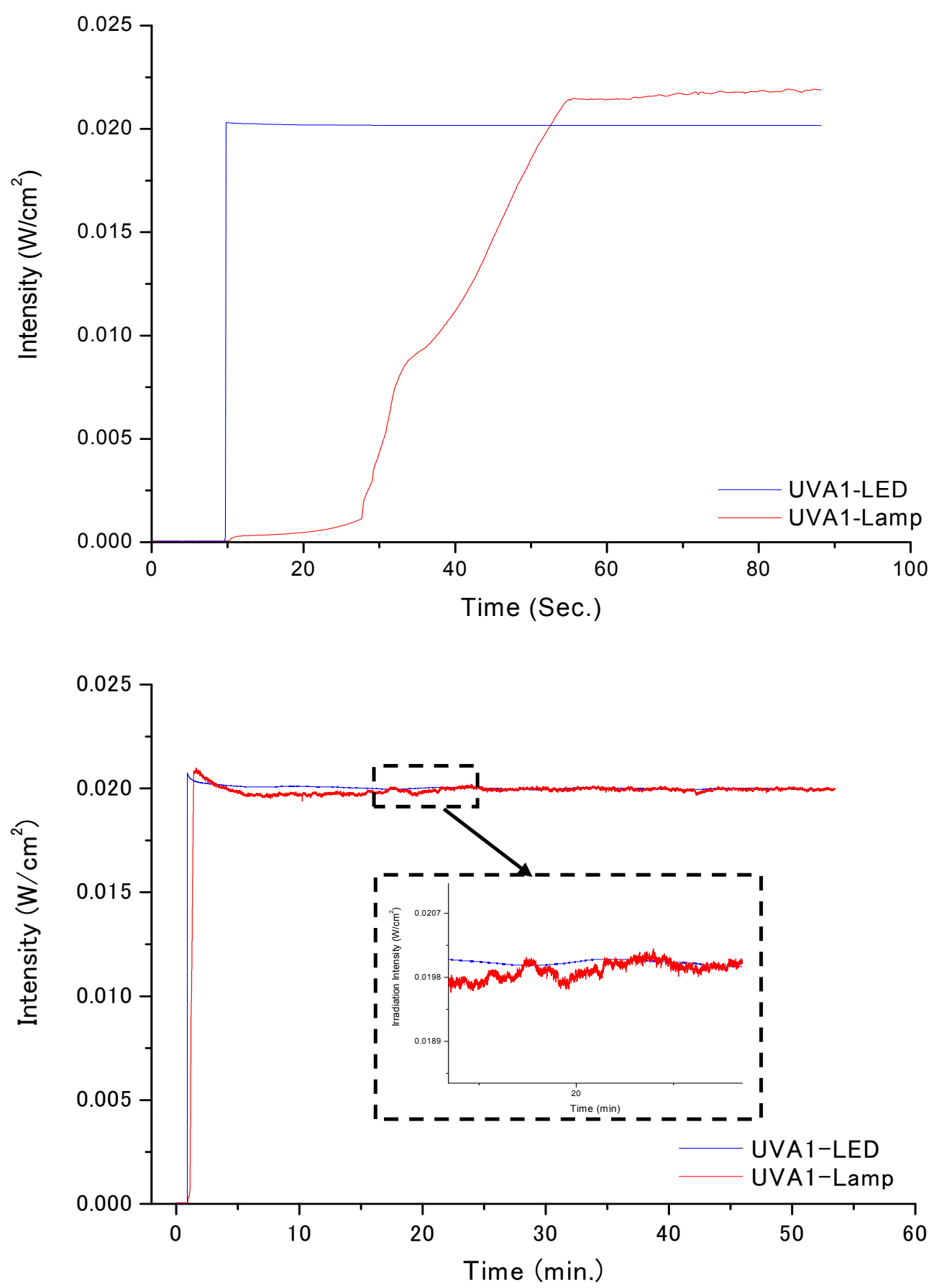

Fig. (4). Irradiation intensity rise time and stability produced by the UV LED and UVA1 lamp devices. (a) Irradiation intensity of UVA1 lamp reached a steady state in approximately $1 \mathrm{~min}$. The irradiation intensity of the UV LED reached a steady state within a few seconds. (b) The UV LED produced more stable irradiation intensity than did the UVA1 lamp.

$\mathrm{cm}$ dishes $(16 \%$ more apoptotic cells in the $3.5-\mathrm{cm}$ dishes than in the $10-\mathrm{cm}$ dishes). The percentage of apoptosis increased with an increase in irradiation, but the difference in apoptosis between $3.5 \mathrm{~cm}$ and $10 \mathrm{~cm}$ dishes was no longer significant.

To confirm that the UVA1 LED and UVA1 lamp devices induced apoptosis, control, sham irradiation, $10 \mathrm{~J} / \mathrm{cm}^{2}, 20$ $\mathrm{J} / \mathrm{cm}^{2}$, and $30 \mathrm{~J} / \mathrm{cm}^{2}$ UVA1 irradiation doses were applied to Jurkat T cells (Fig. 10). As the irradiation dose increased, the percentage of apoptotic cells increased. In the $3.5-\mathrm{cm}$ dishes, an irradiation dose of $30 \mathrm{~J} / \mathrm{cm}^{2}$ significantly increased the number of apoptotic cells. The UVA1 lamp significantly induced 3\% more apoptotic cells than the UVA1 LED. In the $10-\mathrm{cm}$ dishes, all three UVA1 doses $\left(10,20\right.$ and $\left.30 \mathrm{~J} / \mathrm{cm}^{2}\right)$ significantly induced apoptosis. The UVA1 lamp produced a higher percentage of apoptotic cells than the UVA1 LED device $\left(10 \mathrm{~J} / \mathrm{cm}^{2}, 14.9 \% ; 20 \mathrm{~J} / \mathrm{cm}^{2}, 21.4 \%\right.$; and $30 \mathrm{~J} / \mathrm{cm}^{2}$, $3 \%$ ). We initially assumed that, due to thermal effects, more apoptosis would be induced in the $3.5-\mathrm{cm}$ dishes. Instead, the $10-\mathrm{cm}$ dishes exhibited a higher percentage of apoptosis than the $3.5-\mathrm{cm}$ dishes. Although the same concentration of cells was placed in each dish, the thickness of the cell layer 


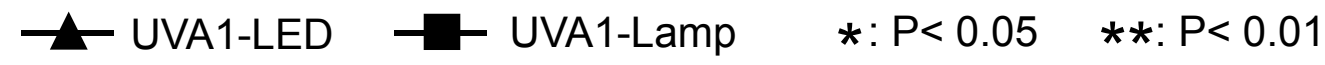

\section{Body Temperature}
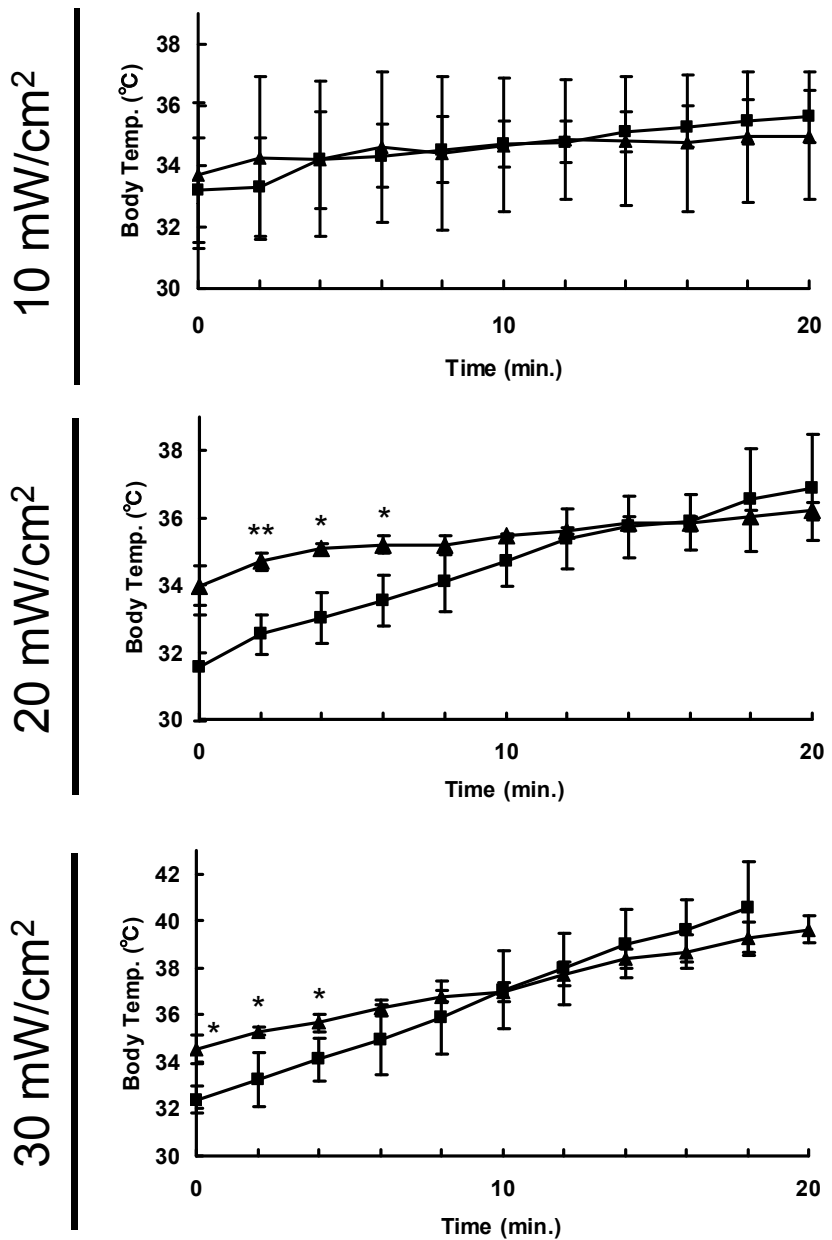

Skin Surface Temperature
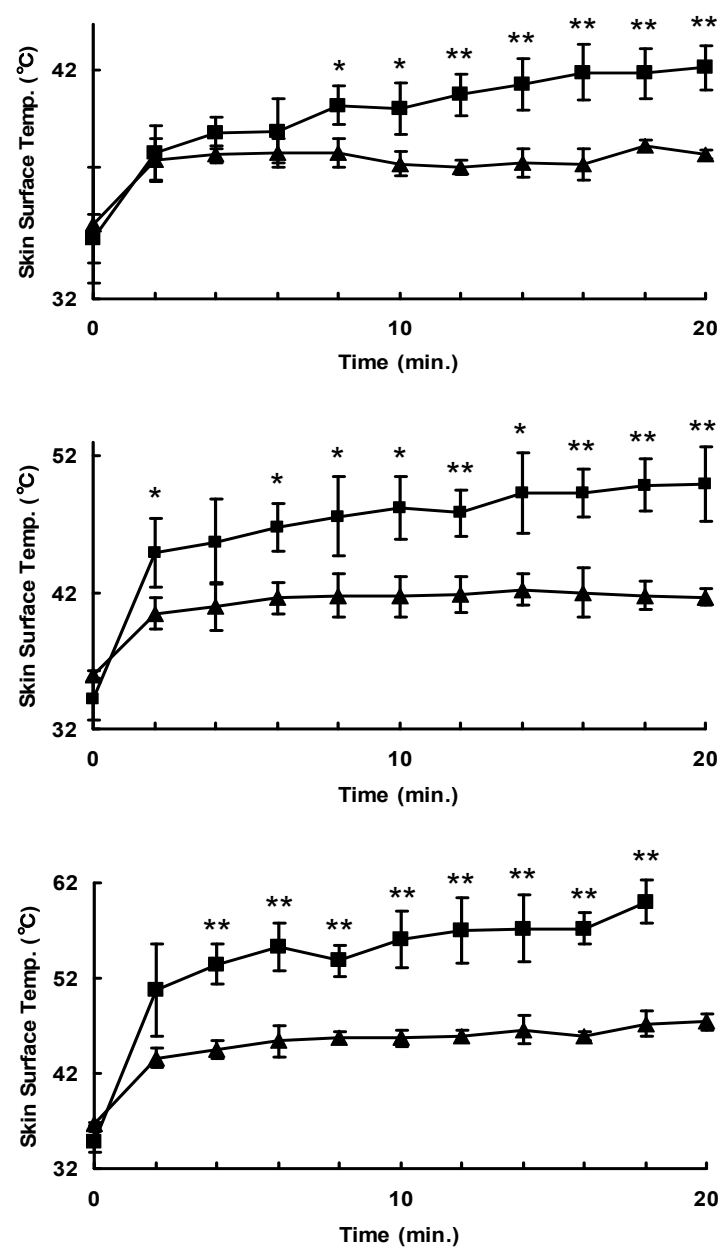

Fig. (5). The temperature characteristics of the UV LED and UVA1 lamp devices were measured using mice. The body and skin surface temperature of mice was measured for $20 \mathrm{~min}$ at irradiation intensities of 10,20 , and $30 \mathrm{~mW} / \mathrm{cm}^{2}$. At 8 min, the body temperature did not differ significantly between light sources. The skin surface temperature of mice irradiated with the UVA1 lamp increased $8^{\circ} \mathrm{C}$ to $10^{\circ} \mathrm{C}$. The UV LED increased skin surface temperature $3^{\circ} \mathrm{C}$ to $4{ }^{\circ} \mathrm{C}$. At $30 \mathrm{~mW} / \mathrm{cm}^{2}$ with the UVA1 lamp, the state became unresponsive at 18 min. At this time, the body temperature was $40.5^{\circ} \mathrm{C}$, and the skin surface temperature reached $60^{\circ} \mathrm{C}$. Results are expressed as means $\pm \mathrm{SD}$ of three independent experiments.

differed. In the 3.5-cm dishes, the cell layer was 1-mm thick, and in the $10-\mathrm{cm}$ dishes the cell layer was $0.2-\mathrm{mm}$ thick. This difference in the surface area is thought to account for the differences in the effect of the UVA1 irradiation on the various plate sizes.

\section{DISCUSSION}

The longer wavelengths of UVA1 phototherapy (340-400 $\mathrm{nm}$ ), which penetrate the dermal layers more deeply that shorter wavelength UVB radiation (290-320 $\mathrm{nm}$ ), effectively treat atopic dermatitis by inducing apoptosis of skininfiltrating $\mathrm{T}$ helper cells [15]. In vitro, the induction of
T helper cell apoptosis is mediated through activation of the FAS/FAS-ligand system in irradiated cells as a consequence of singlet oxygen generation. The generation of singlet oxygen is considered to have a central role in inducing apoptosis and is an underlying mechanism of UVA1 phototherapy [16].

UVA1 was first used to treat patients with atopic dermatitis. The therapeutic efficacy of UVA1 therapy was evaluated in an open study in patients with acute severe exacerbations of atopic dermatitis. UVA1 is highly effective for rapidly inducing clinical improvement in patients exposed to $130 \mathrm{~J} / \mathrm{cm}^{2}$ UVA1 daily for 15 consecutive days 


\section{ㄴ UVA1-LED $\quad$ - UVA1-Lamp $\quad *: P<0.05 \quad * *: P<0.01$}

Partial Irradiation (Size: $8 \mathrm{~cm} \times 3 \mathrm{~cm}$ )

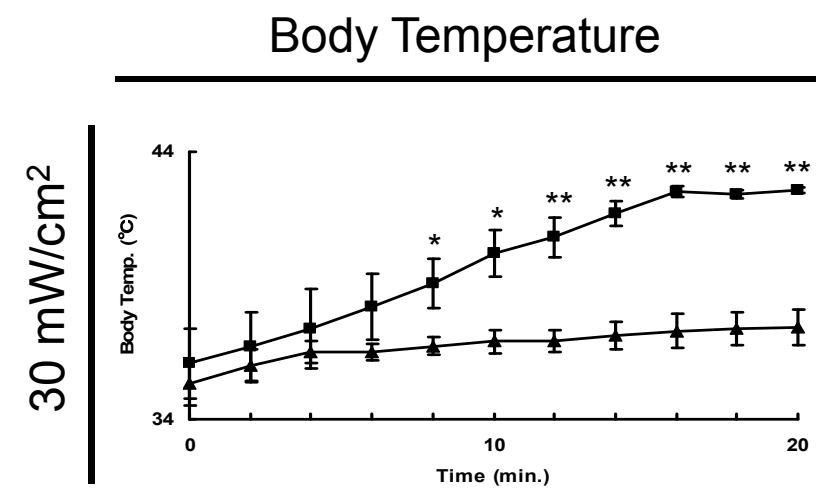

Skin Surface Temperature

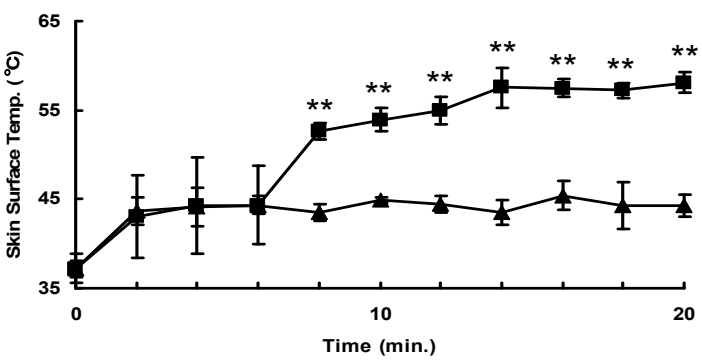

Fig. (6). The selective irradiation function was evaluated. Mice with a body size of approximately $8 \mathrm{~cm} \times 3 \mathrm{~cm}$ were irradiated at an intensity of $30 \mathrm{~mW} / \mathrm{cm}^{2}$ for $20 \mathrm{~min}$ with the UV LED and UVA1 lamp devices. The temperature of both the skin surface and body was measured. The body and skin surface temperature of mice irradiated using UV LED increased very little. The body and skin surface temperatures of mice irradiated with theUVA1 lamp sharply increased. The UVA1 lamp increased the body temperature $5.1^{\circ} \mathrm{C}$ and the skin surface temperature $13.8^{\circ} \mathrm{C}$ more than the UV LED. Results are expressed as means \pm SD of three independent experiments.

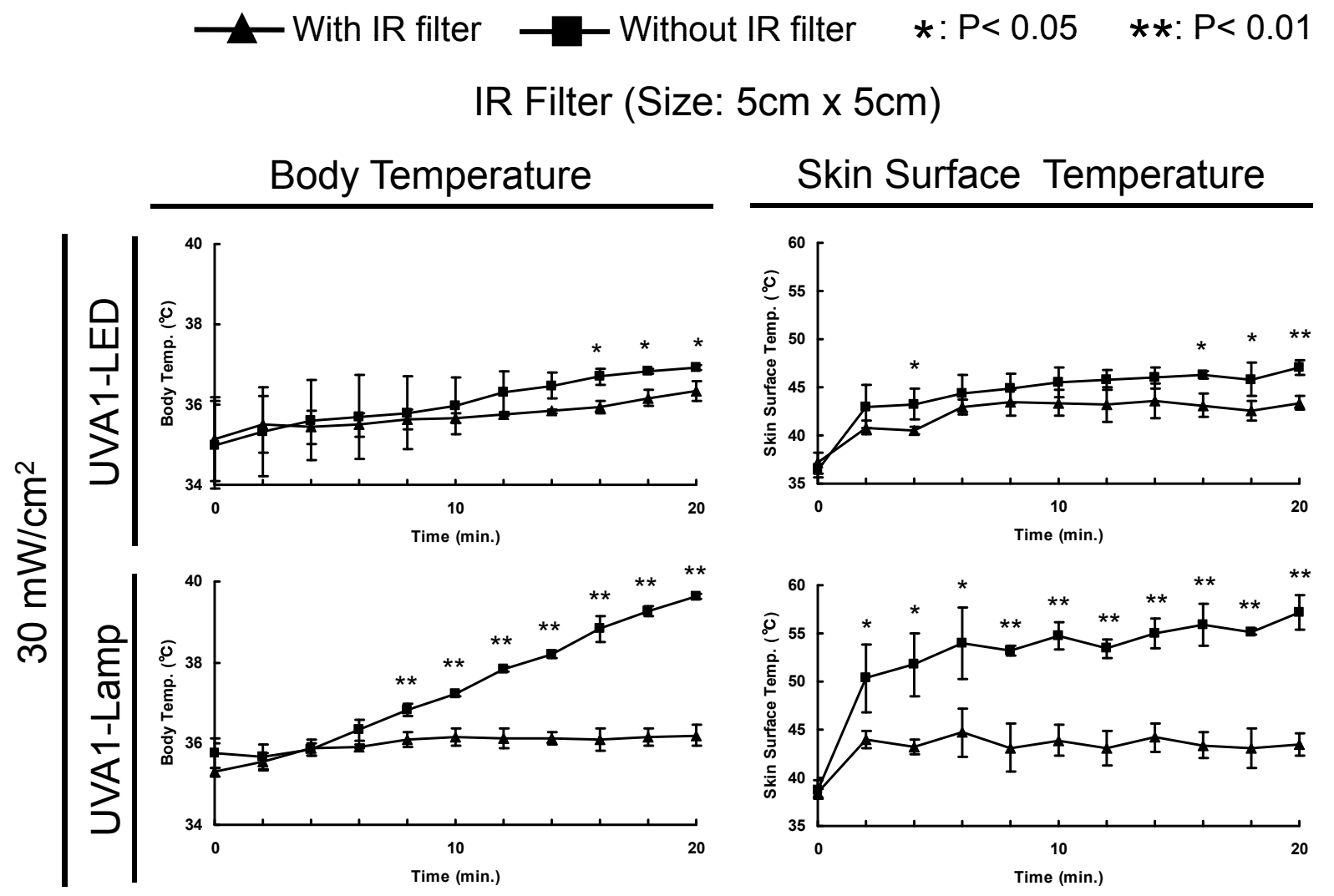

Fig. (7). Mice were irradiated using a far-infrared resonance filter (size: $5 \mathrm{~cm}$ x $5 \mathrm{~cm}$, transparent wavelength: $250-2000 \mathrm{~nm}$ ) for 20 min at an intensity of $30 \mathrm{~mW} / \mathrm{cm}^{2}$ using the UV-LED and UVA1 lamp devices. The temperature of both the skin surface and body was measured with and without the filter to show the effect of the filter on temperature. With the UV-LED device, the differences in the temperature of both the body and the skin surface did not differ significantly with or without the filter. With the UVA1-lamp, the body temperature increased $3.4^{\circ} \mathrm{C}$ more without filter than with the filter, and the skin surface temperature increased $13.7^{\circ} \mathrm{C}$ more without the filter than with the filter. Results are expressed as means \pm SD of three independent experiments. 


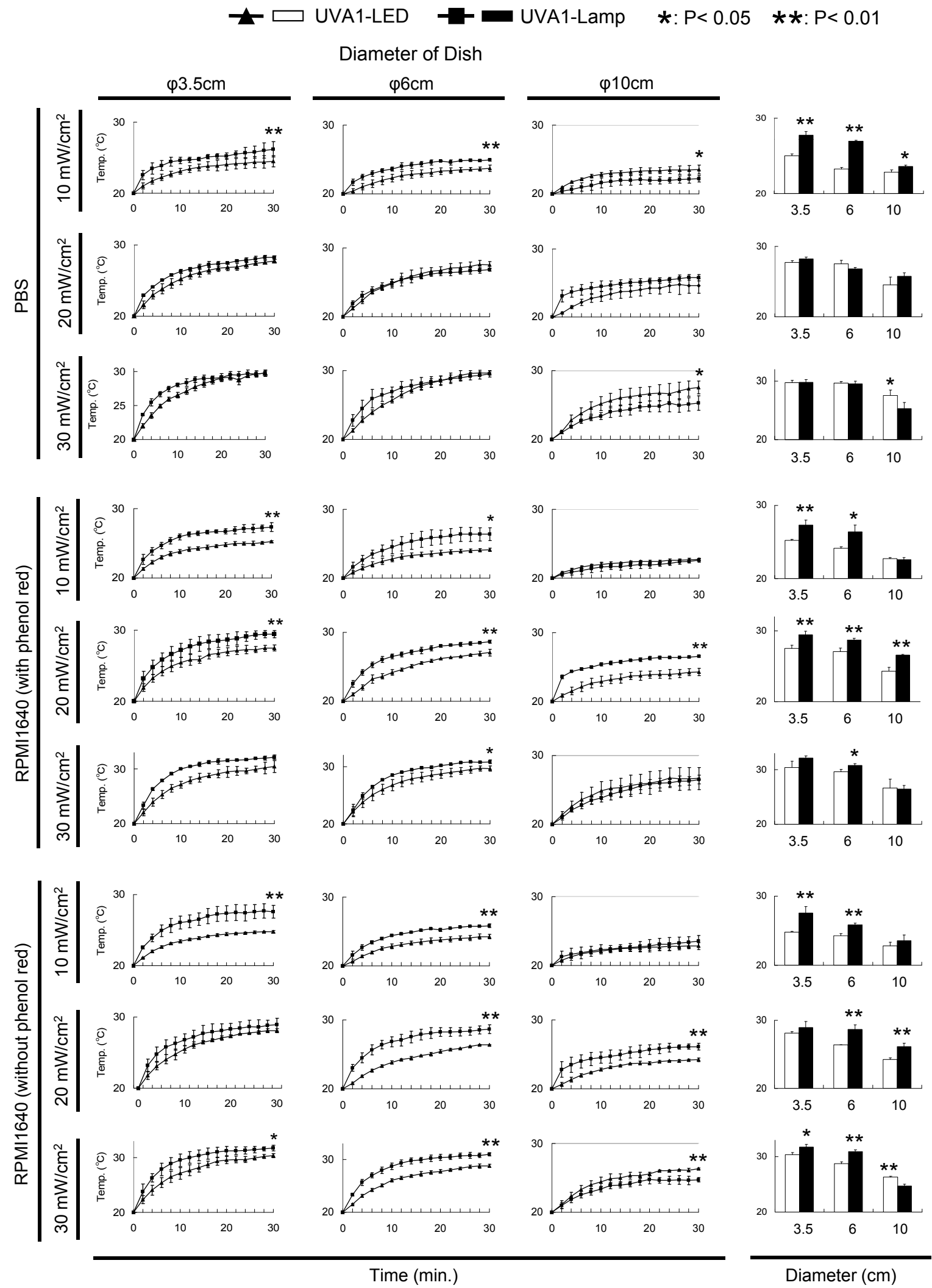

Fig. (8). Phosphate-buffered saline (PBS), RPMI1640 (with phenol red), and RPMI1640 (without phenol red), were placed in culture dishes of various diameters $(3.5,6$, and $10 \mathrm{~cm})$ and evaluated. The amount of medium placed into each dish was: $3.5 \mathrm{~cm}=2 \mathrm{~mL}, 6 \mathrm{~cm}=5 \mathrm{~mL}$, and $10 \mathrm{~cm}=10 \mathrm{~mL}$. Each dish was irradiated with UVA1 $\left(10,20\right.$, and $\left.30 \mathrm{~mW} / \mathrm{cm}^{2}\right)$ for $30 \mathrm{~min}$ using either the UV LED and UVA1 lamp device and the temperature of the medium was measured. The conditions used for measuring the irradiation intensity of UV light only were: $10 \mathrm{~mW} / \mathrm{cm}^{2}, 10 \mathrm{~mL}$ PBS medium, and dish diameter of $10 \mathrm{~cm}$. The conditions used for measuring UV light intensity as well as heat were: $10 \mathrm{~mW} / \mathrm{cm}^{2}, 2 \mathrm{~mL}$ PBS medium, and dish diameter of $3.5 \mathrm{~cm}$. Results are expressed as means \pm SD of three independent experiments. 


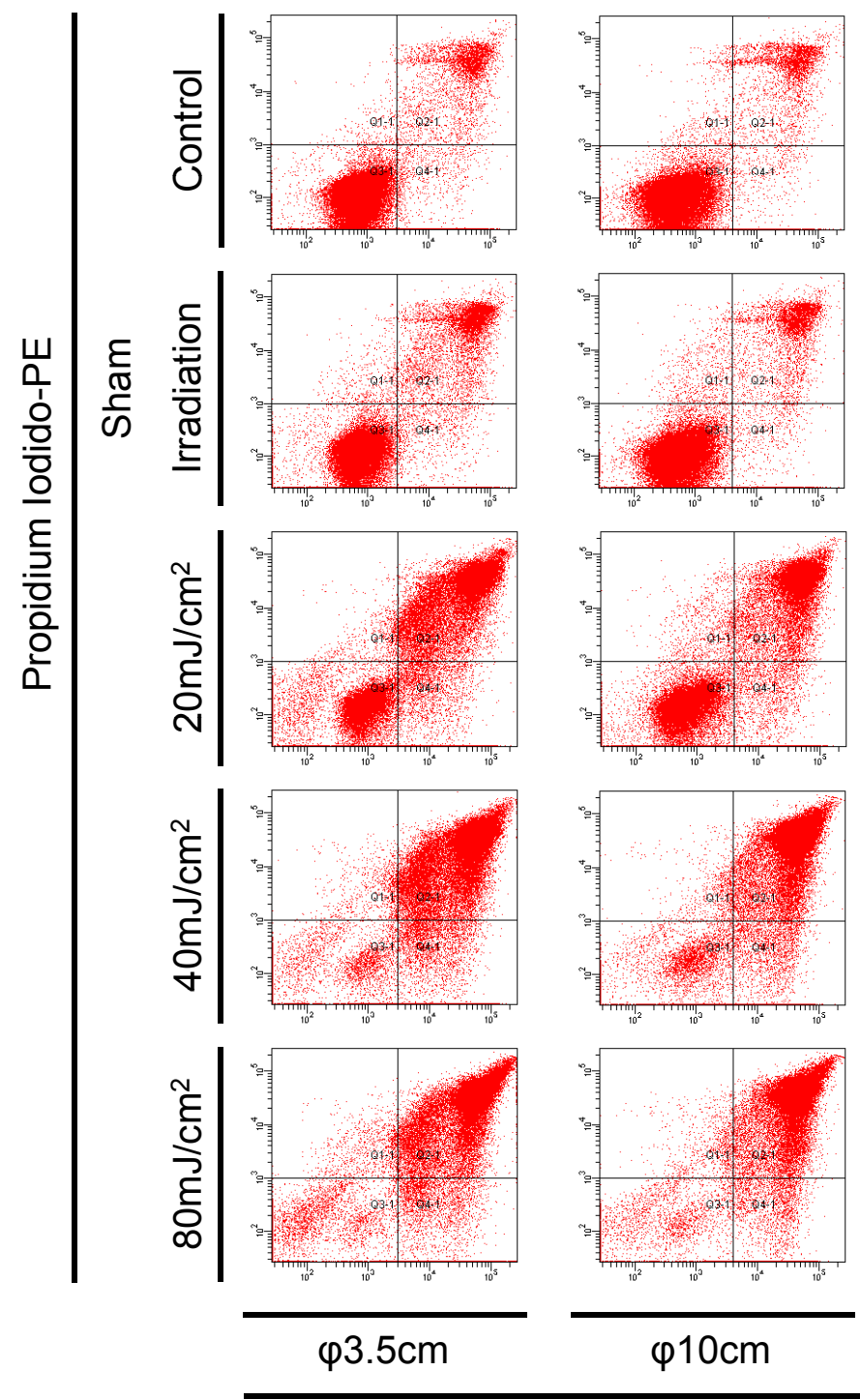

Annexin V-FITC

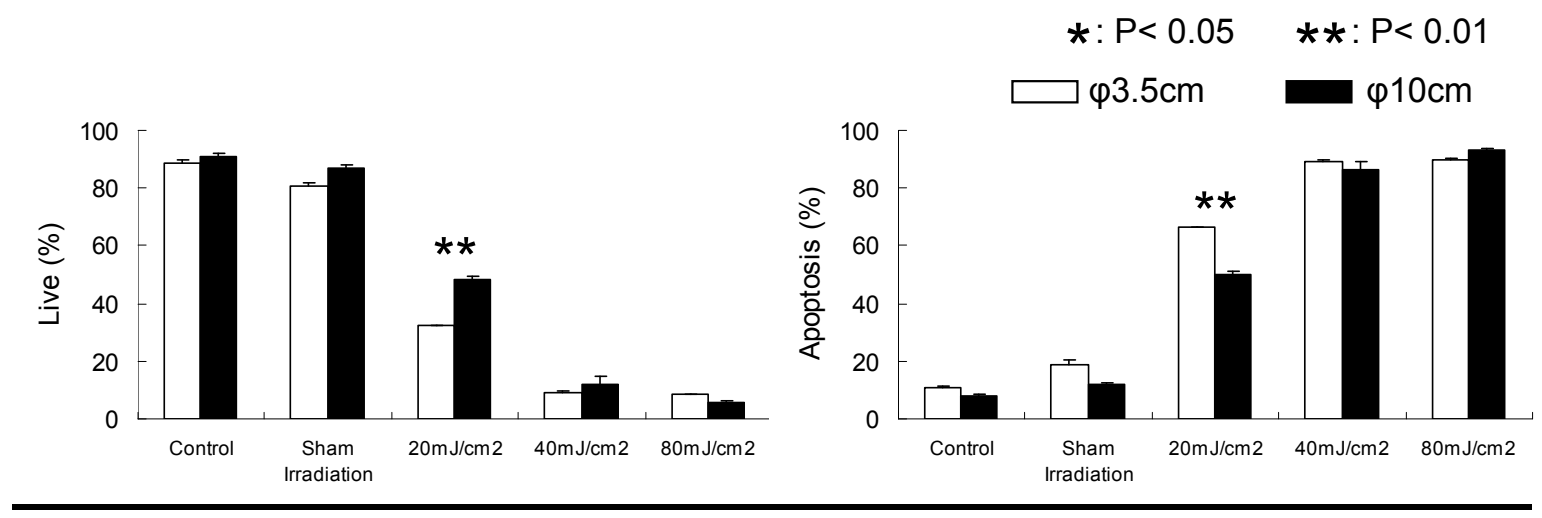

Comparison of $\varphi 3.5 \mathrm{~cm}$ and $\varphi 10 \mathrm{~cm}$

Fig. (9). Control, sham irradiation, $20 \mathrm{~mJ} / \mathrm{cm}^{2}, 40 \mathrm{~mJ} / \mathrm{cm}^{2}$, and $80 \mathrm{~mJ} / \mathrm{cm}^{2}$ BB-UVB irradiation was applied to Jurkat T cells to induce cellular apoptosis. Jurkat T cells $\left(0.5 \times 10^{6}\right.$ cells $\left./ \mathrm{mL}\right)$ were placed in either a $3.5-\mathrm{cm}$ diameter dish $(1 \mathrm{~mL}$ medium $)$ or in a $10-\mathrm{cm}$ dish $(3 \mathrm{~mL}$ medium). At $20 \mathrm{~mJ} / \mathrm{cm}^{2}$ BB-UVB, the percentage of apoptotic cells differed significantly between the $3.5-\mathrm{cm}$ and $10-\mathrm{cm}$ dishes. The difference in percent apoptosis was no longer significant between the $3.5-\mathrm{cm}$ and $10-\mathrm{cm}$ dishes at BB-UVB doses of $40 \mathrm{~mJ} / \mathrm{cm}^{2}$ and 80 $\mathrm{mJ} / \mathrm{cm}^{2}$. The means \pm SD (triplicate determinations) for one representative of three independent experiments is given. 


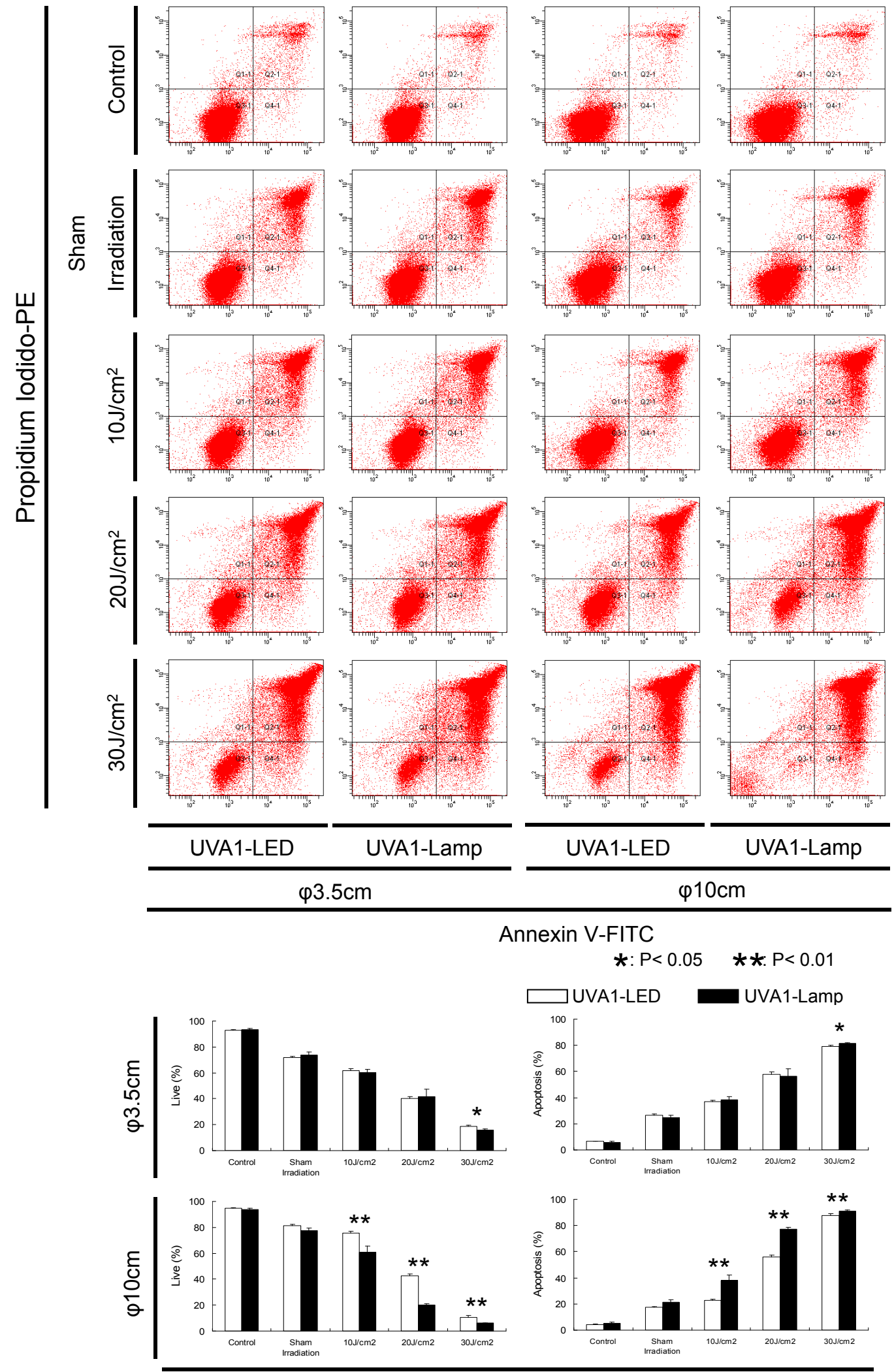

Comparison of UVA1-LED and UVA1-Lamp

Fig. (10). Control, sham irradiation, $10 \mathrm{~J} / \mathrm{cm}^{2}, 20 \mathrm{~J} / \mathrm{cm}^{2}$, or $30 \mathrm{~J} / \mathrm{cm}^{2}$ UVA1 irradiation was applied to Jurkat $\mathrm{T}$ cells using either the UV LED or UVA1 lamp devices to investigate cellular apoptosis. The Jurkat T cells $\left(0.5 \times 10^{6}\right.$ cells $\left./ \mathrm{mL}\right)$ were placed in a $3.5-\mathrm{cm}$ dish $(1 \mathrm{~mL})$ or in a $10-\mathrm{cm}$ dish $(3 \mathrm{~mL})$. In the $3.5-\mathrm{cm}$ dish, the irradiation dose of $30 \mathrm{~J} / \mathrm{cm}^{2}$ induced significantly more apoptosis, and the UVA1 lamp induced $3 \%$ more apoptosis than the UV-LED device. In the $10-\mathrm{cm}$ dish, significantly more apoptosis was induced at doses of 10,20 , and $30 \mathrm{~J} / \mathrm{cm}^{2}$. At all three doses, the UVA1 lamp induced a higher percentage of apoptosis than did the UV LED. The means \pm SD (triplicate determinations) for one representative of three independent experiments is given. 
[17]. UVA1 is also an effective treatment for morphea (localized scleroderma), a disorder characterized by the overproduction of collagen by fibroblasts in affected tissues leading to thickening of the dermis. UVA1 irradiation disturbs cellular responsiveness to tissue growth factor- $\beta 1$ through the induction of non-functional latent tissue growth factor- $\beta$ and the downregulation of tissue growth factor- $\beta$ receptors, which is a possible mechanism underlying the efficacy of UVA1 treatment [18]. Systemic sclerosis is also treated using UVA1 phototherapy. Direct irradiation of the skin with UV rays activates matrix metalloproteinase, reduces the types of cytokines involving $\mathrm{T}$ cells, and inhibits $\mathrm{T}$ cell activation [19]. UVA1 depletes skin-infiltrating $\mathrm{T}$ cells through the induction of $\mathrm{T}$ cell apoptosis and upregulation of matrix metalloproteinase-1 (collagenase-1) expression in dermal fibroblasts [19].

In the present study, we developed a phototherapy device that utilizes UV LEDs to treat refractory skin disease. The UV LED emits UV rays with a peak wavelength of $365 \mathrm{~nm}$ and FWHM of $7 \mathrm{~nm}$. The equipment comprises a $16 \times 16$ UV LED matrix, which can irradiate the diseased part of the skin without affecting the neighboring healthy skin.

To evaluate the performance of the new device, we compared the consumed power, intensity and uniformity of the irradiation, and rise time and stability of the irradiation intensity with that of the conventional UVA1 lamp phototherapy device. In all comparisons, the UVA1 LED device exhibited more favorable characteristics than the UVA1 lamp device. Moreover, the temperature characteristics of both light sources were compared by measuring the body and skin surface temperatures of mice irradiated by the two devices. Although the body and skin surface temperature of mice irradiated with the UVA1 lamp increased sharply, the body and skin surface temperature of mice irradiated with UVA1 LED did not change remarkably. These findings indicate that the UVA1 LED device can be used to treat affected areas of the skin more intensively with less heat compared to the conventional UVA1 lamp.

To confirm that the UVA1 LED and UVA1 lamps could induce cellular apoptosis, Jurkat $\mathrm{T}$ cell cultures were irradiated with BB-UVB, sham irradiation, and $10 \mathrm{~J} / \mathrm{cm}^{2}, 20$ $\mathrm{J} / \mathrm{cm}^{2}$, and $30 \mathrm{~J} / \mathrm{cm}^{2}$ intensities. The experiment was performed in culture dishes with a diameter of $10 \mathrm{~cm}$ to evaluate the effect of UV light only on the cells, or a diameter of $3.5 \mathrm{~cm}$ to evaluate the effect of UV light and heat. The UVA1 lamp induced more cellular apoptosis than the UVA1 LED in each experiment. The UVA1 LED, however, effectively induced apoptosis in the cancer cells.

The findings of the present study demonstrated that the UVA1 LED phototherapy device possibly overcomes problems of conventional UVA1 lamp phototherapy devices. Based on these findings, a clinical study for the efficacy of UVA1 LED phototherapy device has been initiated.

\section{ACKNOWLEDGMENTS}

This work was financially supported by a Grant from the Ministry of Education, Culture, Sports, Science, and Technology, Japan. We would also like to thank Dr. Takashi Mukai (Nichia Chemistry Industry Co, Ltd) for providing the UV LED.

\section{CONFLICT OF INTEREST}

Declared none.

\section{REFERENCES}

[1] Krutmann J, Morita A. Therapeutic photomedicine phototherapy. In: Freedberg IM, Eisen AZ, Wolff K, Austen KF, Goldsmith LA, Katz SI, Eds. Fitzpatrick's dermatology in general medicine. New York: McGraw Hill 2007; pp. 2243-9.

[2] Scherschun L, Kim JJ, Lim HW. Narrow-band ultraviolet B is a useful and well-tolerated treatment for vitiligo. J Am Acad Dermatol 2001; 44: 999-1003.

[3] Krutmann J, Czech W, Diepgen T, Niedner R, Kapp A, Schopf E. High-dose UVA1 therapy in the treatment of patients with atopic dermatitis. J Am Acad Dermatol 1992; 26: 225-30.

[4] Stege H, Schopf E, Ruzicka T, Krutmann J. High-dose UVA1 for urticaria pigmentosa. Lancet 1996; 347: 64.

[5] Mukai T, Morita D, Nakamura S. High-power UV InGaN/AlGaN double-heterostructure LEDs. J Cryst Growth 1998; 189/190: 778-81.

[6] Morita D, Yamamoto M, Akaishi K, et al. Watt class high-outputpower $365 \mathrm{~nm}$ ultraviolet light-emitting diode. Jpn J Appl Phys 2004; 43: 5945-50.

[7] Amano H, Sawaki N, Akasaki I, Toyoda Y. Metalorganic vapor phase epitaxial growth of a high quality GaN film using an AIN buffer layer. Appl Phys Lett 1986; 48: 353-6.

[8] Akasaki I, Amano H. Crystal growth and conductivity control of group III nitride semiconductors and their application to short wavelength light emitters. Jpn J Appl Phys 1997; 36: 5393-408.

[9] Iwaya M, Takanami S, Miyazaki A, et al. High-power UV-lightemitting diode on sapphire. Jpn J Appl Phys 2003; 42: 400-3.

[10] Mukai T, Nakamura S. Ultraviolet InGaN and GaN single-quantumwell-structure light-emitting diodes Grown on epitaxially laterally overgrown GaN substrates. Jpn J Appl Phys 1999; 38: 5735-9.

[11] Gold MH, Andriessen A, Biron J. Self-diagnosis of mild-to-moderate acne for self-treatment with blue light therapy. J Clin Aesthet Dermatol 2009; $2: 40-4$

[12] Jih MH, Kimyai-Asadi A. Laser treatment of acne vulgaris. Semin Plast Surg 2007; 21: 167-74.

[13] Bowler PJ. Impact on facial rejuvenation with dermatological preparations. Clin Interv Aging 2009; 4: 81-9.

[14] Inada AS, Amano H, Akasaki I, Kobayashi K, Morita A. Effect of UV irradiation on the apoptosis and necrosis of jurkat cell using UV LED. Proc SPIE 2009; 7231: 72310J1-6.

[15] Krutmann J, Morita A. Mechanisms of ultraviolet (UV) B and UVA phototherapy. J Invest Dermatol Symp Proc. 1999; 4: 70-2.

[16] Morita A, Werfel T, Stege H, et al. Evidence that singlet oxygeninduced human $\mathrm{T}$ helper cell apoptosis is the basic mechanism of ultraviolet-A radiation phototherapy. J Exp Med 1997; 186: 1763-8.

[17] Krutmann J, Czech W, Diepgen T, Niedner R, Kapp A, Schopf E. High-dose UVA1 therapy in the treatment of patients with atopic dermatitis. J Am Acad Dermatol 1992; 26: 225-30.

[18] Yin L, Morita A, Tsuji T. The crucial role of TGF-beta in the agerelated alterations induced by ultraviolet $\mathrm{A}$ irradiation, J Invest Dermatol 2003; 120: 703-5.

[19] Yin L, Yamauchi R, Tsuji T, Krutmann J, Morita A. The expression of matrix metalloproteinase-1 mRNA induced by ultraviolet A1 (340-400 $\mathrm{nm}$ ) is phototherapy relevant to the glutathione (GSH) content in skin fibroblasts of systemic sclerosis. J Dermatol 2003; 30: 173-80. 